\title{
ПЕРСПЕКТИВЫ РАЗВИТИЯ ДАГЕСТАНСКИХ ЯЗЫКОВ В КОНТЕКСТЕ ЯЗЫКОВОЙ СИТУАЦИИ НА КАВКАЗЕ
}

\section{PROSPECTS OF DEVELOPMENT OF DAGESTAN LANGUAGES IN THE CONTEXT OF THE LANGUAGE SITUATION IN THE CAUCASUS}

\section{B. Ataev \\ M. Ibragimova}

Summary: The article analyzes the language situation in Dagestan, considers the necessary conditions for the survival of national languages with different social status and the prospects of their Association with the languages of more numerous peoples. The problems connected with language policy are investigated, the reasons of the process of disappearance of minority languages are analyzed and the conditions under which their preservation is possible are discussed. The project of the target state program on preservation, development and functioning of languages of the peoples of Dagestan is offered.

Keywords: Dagestan languages, language situation, minority languages, preservation of languages.
Д.филол.н., профессор, г.н.с., ИЯЛИ ДФИЦ РАН (г. Махачкала) bm_ataev@mail.ru

Ибрагимова Мариза Оглановна Д.филол.н., дочент, в.н.С., ИЯЛИ ДФИЦ РАН (г. Махачкала) mariza71@mail.ru

Аннотация: В статье анализируется языковая ситуация, сложившаяся в Дагестане и за пределами республики и Российской Федерации, в странах, где компактно проживают носители генетически родственных дагестанских языков. Определяются необходимые условия для выживания национальных языков с разным социальным статусом и прогнозируются перспективы их сосуществования с языками более многочисленных народов. Исследуются проблемы, связанные с языковой политикой, анализируются причины процесса исчезновения миноритарных языков и предлагается комплекс мер по сохранению и развитию дагестанских языков.

Ключевые слова: дагестанские языки, языковая ситуация, миноритарные языки, сохранение языков.
Я зыковая ситуация на Кавказе в целом характеризуется многокомпонентностью единиц. В Республике Дагестан функционируют двадцать восемь языков, относящихся к трём языковым семьям, и около ста диалектов и говоров. Выявляются существенные различия между дагестанскими языками по количеству носителей, по ареалу распространения, по числу обслуживаемых коммуникативных сфер и по функционированию доминирующих литературных языков.

Качественные признаки языковой ситуации также разнообразны: на Кавказе (в ареале распространения исследуемых нами языков Дагестана) представлены языки нескольких генетических групп: нахско-дагестанской (нахской - чеченский язык; дагестанской - аварский, агульский, андийский, арчинский, ахвахский, багвалинский, бежтинский, ботлихский, будухский, гинухский, годоберинский, гунзибский, даргинский, каратинский, крызский, лакский, лезгинский, рутульский, табасаранский, удинский, хваршинский, хиналугский, цахурский, цезский, чамалинский языки); тюркской (азербайджанский, кумыкский и ногайский языки); индоевропейской (русский и татский языки).

Дагестанские различаются по своему статусу: письменно-литературными являются аварский, даргинский, лакский, лезгинский, табасаранский, агульский, рутульский, цахурский, которые наряду с русским, кумыкским, азербайджанским, ногайским и татским признаны государственными языками Республики Дагестан; бесписьменными дагестанскими языками с минимальными общественными функциями являются андийский, арчинский, ахвахский, багвалинский, бежтинский, ботлихский, будухский, гинухский, годоберинский, гунзибский, каратинский, крызский, тиндинский, удинский, хваршинский, хиналугский, цезский и чамалинский языки. Заметная градация наблюдается и внутри групп языков с равным статусом: агульский, рутульский и цахурский языки стали письменными лишь в 1990 году, вследствие чего функции их как языков письменных незначительны на фоне других активно функционирующих государственных языков республики. 
С социолингвистической точки зрения языки народов Дагестана также неоднородны, что обусловливает необходимость пристального внимания лингвистов к правовым вопросам функционирования языков [Биткеева 2018; Алексеев 1992; Алексеев 2013: 11-12; Языки народов России 2002; Государственные языки Российской Федерации 1995; Габуниа, Тирадо 2002 и др.].

Характерной особенностью истории языковой ситуации в регионах проживания носителей дагестанских языков является противоречивость тенденций:

- неотъемлемое право личности на выбор языка, соседствующее с угрозой исчезновения языка малочисленного народа и самого этноса вследствие массового отторжения от родного языка;

- естественное стремление билингвов к достижению соответствия родного языка уровню их духовного развития на фоне недостижимости осуществления такой адекватности;

- регулярные призывы к изучению родного языка горожанами, не знающими его, наталкивающиеся на невозможность создания экстралингвистических условий, стимулирующих необходимость знать его;

- рост социальной престижности русского языка, граничащий с ухудшением положения с его изучением и низким общим уровнем культуры русской речи;

- признание на словах жизненной необходимости русского языка как важнейшего фактора интеграции разноязычных национальностей Дагестана при сокращении вузах Дагестана, часов, отводимых на его изучение.

Исторически в Дагестане межнациональное общение осуществлялось на нескольких языках: в религиозной сфере духовные лица переписывались и осуществляли устное общение на арабском языке; в торгово-экономической и хозяйственно-деловой сфере применялись кумыкский и азербайджанский языки; в качестве локально ограниченного средства межэтнического общения носителями бесписьменных аваро-андо-цезских языков использовался и продолжает использоваться аварский язык, для носителей будухского, крызского и хиналугского языков в этой роли выступает азербайджанский язык.

Современные дагестанские языки представляют собой достаточно пеструю картину не только с точки зрения их структурного своеобразия или же сложности генетических взаимоотношений, но и в плане своего социального статуса. Среди них, в частности, мы выделяем «следующие группы языков, обнаруживающих примерно равные социальные условия функционирования:

1. литературные дагестанские языки, на которых ведется преподавание в начальной школе, изучаемые как предмет в средней и высшей (по фило- логическим специальностям) школе, на которых издается художественная, общественно-политическая и методическая литература, выходит периодическая печать и др.: аварский, даргинский, лезгинский, лакский и табасаранский;

2. новописьменные языки: агульский, рутульский, цахурский;

3. бесписьменные языки с определенным ареалом распространения, на которых говорят этносы, не имеющие официального статуса: андийский, ботлихский, годоберинский, каратинский, ахвахский, багвалинский, тиндинский, чамалинский, цезский, бежтинский и хваршинский;

4. бесписьменные «одноаульные» языки: арчинский, гинухский, гунзибский;

5. бесписьменные языки, носители которых проживают только за пределами Российской Федерации - будухский, крызский, хиналугский, удинский. Будухский и крызский языки локализованы на территории Кубинского и Хачмазского районов Республики Азербайджан, носители хиналугского языка компактно проживают в селе Хиналуг Кубинского района Республики Азербайджан. В отношении этих языков А. Юнусов отмечает, что «...В переписях они также не отмечались, в том числе и в последней. Но считается, что их в общей сложности около 10 тысяч человек» [Юнусов 2001]. Носителей удинского языка, проживающих компактно в Габалинском и Огузском районах Республики Азербайджан, по переписи 1999 года зафиксировано 4,2 тысячи, проживающих в основном в селе Нидж, и 104 человека, проживающих в Кахском районе. [Юнусов 2001]. Также удины проживают в Кварельском районе Грузии, в селе Зинобиани;

6. некоторые современные кавказоведы выделяют в качестве отдельных единиц и бесписьменные языки малочисленных народов, традиционно считавшиеся диалектами даргинского языка: кайтагский и кубачинский» [Атаев 2012: 170-171].

Носители письменных дагестанских языков проживают и за пределами Дагестана: в Азербайджанской Республике представлены следующие литературнописьменные языки - лезгинский (по данным А. Юнусова «численность лезгин в Азербайджане колеблется в пределах 250-260 тысяч человек» [Юнусов 2001], в основном, в Кусарском и Кубинском районах), аварский (по подсчетам американских специалистов - членов Группы Северной Евразии Международного Летнего Института Лингвистики «количество аварцев только в Закатальском и Белоканском районах составляло около 57 тысяч человек» [Clifton et all 2003: 3-4]), цахурский (15, 9 тыс. чел. в Закатальском и Кахском районах [Юнусов 2001]). 
Свыше 2 тысяч носителей ахвахского языка (по оценочным данным) локализованы в сел. Охох-дере Закатальского района Республики Азербайджан.

Носители бежтинского и гунзибского языка (свыше 5 тысяч чел.) компактно проживают в сс. Тиви, Сарусо, Чантлискуре и Тхилискаро Кварельского района Грузии). Носители чамалинского языка проживают в Чеченской Республике (около 2 тысяч человек в сел. Кенхи Шаройского района).

Большое количество выходцев из Цунтинского и Цумадинского районов Дагестана проживает и в других населенных пунктах Чеченской Республики. Например, в станице Бороздиновская Шелковского района ЧР аварцы составляют свыше 90\% населения. «В целом, по официальным данным Всероссийской переписи населения 2002 г. в Чеченской Республике проживает 4133 аварца» [Национальный состав и владение языками, гражданство 2004: 64].

Потомки аварцев проживают также в некоторых странах Ближнего Востока: Турции, Сирии, Иордании, Ираке, Египте и Саудовской Аравии. В частности, в Турции (в 1981 г.) только лишь в трёх селениях Гюней-кей, Эсадие и Султание близ города Яловы насчитывалось около 10 тыс. потомков аварцев (по оценке французского исследователя Ж. Шарашидзе [1981], изучавшего в этих сёлах аварскую речь).

Таким образом, языковая ситуация, сложившаяся в регионе локализации дагестанских языков, - это исторически существующее по своим законам социолингвистическое явление, на которое политико-административные границы практически не оказывали существенного влияния.

Аварский, азербайджанский, кумыкским, лакский языки, выступавшие в качестве вторых в силу объективных географических, экономических и социально-политических обстоятельств целыми группами народов использовались как региональные языки межнационального общения. Региональные языки аварский в Западном Дагестане (для народов андийской, цезской групп, арчинцев и др.), азербайджанский язык в Южном Дагестане (для лезгин, рутулов, цахуров, табасаранцев, будухов, крызов, хиналугов, удин, а также для татов), лакский язык в Центральном Дагестане (для агулов, аварцев, арчинцев, даргинцев, в том числе кубачинцев и нижнекатрухских азербайджанцев), кумыкский язык в Северном Дагестане (для аварцев, даргинцев) выполняли функции не только языка устного межнационального общения, но в известной мере и языка обряда.

Степень функциональной активности по всем позициям этих языков как языков межнационального обще- ния не была одинаковой. Региональные языки по своей распространенности, по активности употребления, по количеству сфер употребления и по объему выполняемых функций, наконец, по своему престижу заметно отличались друг от друга.

Количество функций, выполнявшихся дагестанскими литературными языками, объем каждой отдельной функции, степень активности употребления языка в той или иной общественной сфере зависели не только и не столько от «качеств» самого языка, сколько от экстралингвистических условий их функционирования в тогдашнем Дагестане, которые, в свою очередь, определялись экономической и политической жизнью, уровнем социального развития населения и его культурной ориентации. Поэтому дагестанские литературные языки (аварский, даргинский, кумыкский, лакский, лезгинский, табасаранский и др.) по своим общественным функциям и широте сфер употребления, по характеру нормализационных процессов и уровню нормированности, а также по степени обособленности от разговорной формы представляли довольно пеструю картину, и по этим параметрам их нужно отнести к разным типам литературных языков.

Среди мероприятий, способных стабилизировать лингвистическую ситуацию в Дагестане, безусловно, выделяется введение письменности, позволяющее определенным образом законсервировать оригинальную лексику и своеобразные грамматические конструкции. Важно при этом подчеркнуть, что фиксация этого в научных грамматиках и словарях ни в коей мере не способна заменить живой язык, являющийся неотъемлемой частью духовного богатства человечества. Однако деятельность по введению письменности должна, на наш взгляд, предусматривать, по крайней мере, два компонента: во-первых, обучение чтению и письму на родных языках (что потребует создания букварей) и, во-вторых, собирание фольклора не только как аккумулятора духовной культуры, но и в практических целях: для подготовки материалов по чтению в младших классах и в семье. Дополняемые достаточно полными словарями, эти меры помогут определенной стабилизации грамматической структуры и словарного фонда бесписьменных языков.

Анализ сложившейся языковой ситуации в Дагестане не позволяет прогнозировать неминуемое исчезновение бесписьменных языков малочисленных народов путем слияния с языком более многочисленного народа. Бесписьменные языки Дагестана функционируют в своих узких сферах общения, их носители, владея, к примеру, и аварским литературным языком, являются билингвами. Знание русского языка делает их полилингвами.

Мы полагаем, что в ареале распространения даге- 
станских языков намечаются следующие перспективы развития языковой ситуации:

1. Несмотря на нынешние, казалось бы, непреодолимые трудности, намечается рост числа дагестанцев, заинтересованных в сохранении языка этносов, обучении детей родному языку, что прогнозирует подъём этнического самосознания дагестанцев.

2. Интенсивно будет расширяться круг носителей национально-русского двуязычия, что приведет к повышению интереса к овладению обоими языками в совершенстве.

3. Активизация в области изучения родных языков горожанами-билингвами приведет к стиранию противоречий между суверенным правом личности на выбор языка общения, образования и интересами сохранения этногенофонда малочисленных народов.

4. В связи со спецификой полиэтнического региона не намечается принятие решения о требовании от граждан других национальностей, живущих в Дагестане, овладения «одним из местных языков (по выбору)». Такое требование, вполне оправданное в мононациональном регионе, в Дагестане выглядит капризом некомпетентных специалистов, так как в республике отсутствуют сферы общения, в недостаточной мере обслуживаемые русским языком. Алогизм постановки вопроса обусловлен изначальным отсутствием критериев выбора одного из дагестанских языков.

Факт включения 21 дагестанского языка с числом носителей менее 50000 человек из 26 дагестанских языков нахско-дагестанской языковой семьи в разработанный ЮHECKO «Atlas of the World's Languages in Danger» [2010], свидетельствует о том, что эти языки на современном этапе истории нуждаются в сохранении и развитии, как в полиэтническом Дагестане, так и в других регионах Кавказа с компактным проживанием их носителей. Решение этих проблем требует государственного внимания и заботы со стороны руководства Дагестана.

На республиканском уровне в целях проведения более эффективной языковой политики необходимо разработать продуманную целевую государственную программу по сохранению, развитию и функционированию языков народов Дагестана, в которой должно быть предусмотрено:

- системное изучение языковой ситуации в Дагестане; поддержка дагестанских языков; сохранение, возрождение и их развитие за пределами республики;

- научное исследование дагестанских языков, их истории и современного состояния, процессов взаимодействия между этнокультурными и языковыми общностями, межкультурного и межъя- зыкового общения, характера двуязычия и многоязычия;

- в отношении будухского, крызского, удинского и хиналугского языков, локализованных только за пределами Российской Федерации:

а) реализация ряда исследовательских мероприятий, предполагающих сбор и фиксацию языкового и фольклорного материала для дальнейшего его сравнения с фактами родственных языков для построения диахронических сценариев прадагестанского и пралезгинского уровней;

б) включение в планы исследовательских кавказоведческих центров составление крызко-русского и удинско-русского словарей (хиналугскорусский и будухско-русский словари составлены ранее);

В) организация научных экспедиций сотрудников Института языкознания РАН и Института языка, литературы и искусства им. Г. Цадасы Дагестанского федерального исследовательского центра РАН для сбора национальных текстов на крызском, будухском, хиналугском и удинском языках (при сотрудничестве с научными центрами Peспублики Азербайджан);

г) составление национальных корпусов шахдагских языков с целью фиксации текстов исчезающих языков для их дальнейшего сохранения;

- поддержка различных средств массовой информации, радио-, теле- и кинокомпаний, осуществляющих вещание и создание фильмов на языках народов Дагестана;

- разработка и внедрение проекта, специально ориентированного на образовательный аспект сохранения и возрождения дагестанских языков, предусматривающего развернутую постановку обучения родному языку в семье, в детских учреждениях, младших классах школ; создание и выпуск азбук, букварей и других учебных пособий, радио- и телевизионных программ; целевую подготовку и переподготовку учительских кадров и т. д. В частности, следует подумать о создании для малочисленных андо-цезских этносов и арчинцев своего варианта учебника аварского языка для начальных классов, адаптированного к их родным языкам. Думается, что «... стало бы важным фактором сохранения языка, самобытной региональной культуры и фольклора, укрепления самосознания и осознания той роли, которую они органично занимают в составе аварского народа и в родственном кругу других народов Дагестана» [Атаев, Атаева 2015: 83].

- разработка мероприятий по подготовке кадров и совершенствованию системы народного образования на языках народов Дагестана;

- содействие изданию художественной, публицистической, научной, учебной литературы на род- 
ном языке, публикации фольклорных текстов и памятников словесности;

- более эффективное внедрение новейших информационных технологий в сферу образования и использование родных языков при обучении национальных меньшинств в других субъектах Российской Федерации, к примеру, дистанционное обучение родным языкам для дагестанцев, проживающих за пределами республики в РФ;

- поощрение использования лучших традиций народной педагогики в целях воспитания толерант- ной личности, способной уважать мировоззрение, религию, национальность другого человека, а также формирование разумного сочетания различных уровней идентичности: этнической, религиозной, общедагестанской, общероссийской

В Республике Дагестан необходимо сохранить положительный опыт этнической консолидации и проводить последовательную этноязыковую политику, ориентированную на сохранение и развитие дагестанских языков.

\section{ЛИТЕРАТУРА}

1. М.Е. Алексеев. Языки малочисленных народов СССР: современное состояние и перспективы// Проблемы языкознания в СССР: 1987 1999 гг. М., 1992. С. $13-24$.

2. М.Е. Алексеев. Языки народов России и постсоветского пространства: проблемы изучения и перспективы развития // Родной язык 1. 2013. С. 8-17.

3. Б.М. Атаев. Миноритарные языки Дагестана: состояние и перспективы. Махачкала: ИЯЛИ ДНЦ РАН, 2012.

4. Б.М. Атаев, М.Б. Атаева. Миноритарные языки Дагестана: статистический обзор и особенности функционирования // Вестник ВЭГУ 3. 2015. С. 77-84.

5. А.Н. Биткеева. Языковая адаптация диаспоры: стратегия и перспективы развития // Acta Linguistica Petropolitana T.14, Часть 3., 2018. С. 57-81.

6. З.М. Габуниа, Р. Г. Тирадо. Миноритарные языки в XXI веке. Кавказские языки. М.: ИЯ РАН-КБГУ, 2002.

7. Государственные языки в Российской Федерации: Энциклопедический словарь-справочник/ Гл. ред. В.П. Нерознак. М.: «Academia», 1995.

8. J. Clifton, J. Mak, G. Deckinga, L. Lucht, C. Tiessen. The Sociolinguistic Situation of the Avar in Azerbaijan // Studies in Languages of Azerbaijan / Ed. by John M Clifton / Inst. of Intern. Rel. Acad. of Sciences of Azerbaijan / SIL International. - Baku St Petersburg, 2003.Vol. 2.

9. Ch. Moseley. Atlas of the World's Languages in Danger. - Paris: UNESCO, 2010.

10. Народы Дагестана. М.: Наука, 2002.

11. Национальный состав и владение языками, гражданство: итоги Всероссийской переписи населения 2002 г. Т. 4. Кн. 1-2. М., 2004.

12. А. Юнусов. Этнический состав Азербайджана (по данным переписи 1999 г.). Баку, 2001. http://www.iea.ras.ru/topic/census/mon/yunus_mon2001.htm

13. Языки народов России. Красная книга. Энциклопедический словарь-справочник. М.: «Academia», 2002. 